\title{
Correction to: Tests for segmented cointegration: an application to US governments budgets
}

\author{
Luis F. Martins ${ }^{1,2}$ (D) Paulo M. M. Rodrigues ${ }^{3}$
}

Published online: 27 December 2021

๑) Springer-Verlag GmbH Germany, part of Springer Nature 2021

\section{Correction to: Empirical Economics https://doi.org/10.1007/s00181-021-02156-7}

In the original publication of the article, the affiliation "CIMS, University of Surrey, Guildford, UK" was incorrectly tagged to the author "Paulo M. M. Rodrigues". It should have been tagged to the author "Luis F. Martins". The original article has been corrected.

Publisher's Note Springer Nature remains neutral with regard to jurisdictional claims in published maps and institutional affiliations.

The original article can be found online at https://doi.org/10.1007/s00181-021-02156-7.

$\bowtie$ Luis F. Martins

luis.martins@iscte-iul.pt

1 ISCTE-IUL, BRU-IUL, Lisbon, Portugal

2 CIMS, University of Surrey, Guildford, UK

3 Banco de Portugal, NOVA School of Business and Economics, Carcavelos, Portugal 